\title{
A Sectoral Analysis of Ontario's Weak Productivity Growth
}

\author{
Peter S. Spiro ${ }^{1}$ \\ Mowat Centre for Policy Innovation \\ University of Toronto
}

\begin{abstract}
Since 2005, labour productivity growth in Ontario's business sector has been zero, greatly under-performing the rest of Canada and being single-handedly responsible for most of what has been described as "Canada's dismal productivity growth." This article examines the issue through detailed sectoral data, and finds a wide range of variation underlying the average productivity growth rate. Some important sectors have maintained decent productivity growth. Other sectors, especially in manufacturing, saw the level of productivity decline significantly. Empirical evidence suggests that weak aggregate demand-due to the high Canadian dollar, the U.S. recession, and global restructuring-was the main cause of weak productivity. Weak demand led to lost economies of scale, particularly due to compositional shifts in the economy.
\end{abstract}

ONE OF THE MOST WIDELY used economic performance indicators is labour productivity, defined as real GDP per hour worked. ${ }^{2}$ Ontario's performance in terms of labour productivity has been very poor over the past several years. This has caused a considerable amount of concern. It is widely noted that, in the long run, increases in real wages and living standards come mainly from productivity growth. ${ }^{3}$

When Canadian economists talk about competitiveness, they almost always bring in the subject of productivity. Many argue that Canada's poor productivity growth has caused interna- tional competitiveness to decline. Certainly, our economy appears less competitive than it used to be, based on the evidence of Canada's large trade deficit. If Canadians could be induced to work harder or smarter to boost productivity, it is claimed, competitiveness would improve.

But what if it sometimes works the other way around? What if it is competitiveness that affects productivity growth? That is to say, what if an overvalued exchange rate, by reducing competitiveness and the scale of output, causes lower productivity growth?

This article argues that productivity, when constrained by demand factors, is not an inde-

1 Peter S. Spiro is Executive Fellow, Mowat Centre for Policy Innovation, School of Public Policy and Governance, the University of Toronto. An earlier version of this article was presented at the annual meeting of the Canadian Economics Association in Montreal, May 31-June 2, 2013. The author has benefited from the comments of Andrew Sharpe, Jianmin Tang, Wulong Gu, Christopher Ragan, Alvaro del Castillo, Matthias Oschinski, and two anonymous referees. Email: spiropeter@gmail.com.

2 All references to productivity in this article refer to labour productivity.

3 It should be noted, however, that there is no fixed relationship between productivity and real wage growth. Such a relationship would only exist if the economy was characterized by a simple Cobb-Douglas type production function. Most empirical evidence does not support it. Changes in the relative prices of imports and exports can also play a significant role in raising the standard of living. This is the main reason why Alberta has been doing so well in terms of real income growth. 
pendent causal factor that determines standards of living. While there are many reasons for anxiety about the Ontario economy, an excessive focus on low productivity growth, as if it was always a driving factor, is misplaced.

There is both a demand side and a supply side to productivity. From the supply side, there is potential for productivity growth when technology improves, and when workers become more educated and have more and better capital equipment to work with. However, this potential will not be realized if there is insufficient demand. If highly educated individuals are relegated to driving cabs or selling shirts, their investment in education will be wasted. If more output cannot be sold, it will not make sense for companies to invest in more and better equipment to increase output.

Business commentators generally focus on the average productivity growth for the whole economy. If most industries were clustered close to this average, it would be a meaningful indicator. In fact, this average can be misleading, inasmuch as it is the random outcome of a wide range of different sub-components and may therefore not be representative. In order to understand productivity, it is necessary to see what lies beneath, and to look at its performance at the detailed sectoral level. The possibility of doing this has been facilitated by a new experimental database from Statistics Canada that provides detailed sectoral productivity by province. ${ }^{4}$ As we peel away the layers, it will be possible to better understand why productivity growth has slowed so sharply in Ontario.

The article consists of seven sections. The first section provides a brief overview of Ontario's productivity performance. The second section illustrates how the composition of output can affect aggregate productivity. The third section examines the effect of export demand on the composition of output, along with implications for productivity. The fourth section looks at service sector productivity. The fifth section presents a three-digit NAICS decomposition of Ontario's productivity growth. The sixth and most important section provides a regression analysis of the relationship between output and productivity growth in manufacturing. The seventh and final section concludes and provides directions for future research.

\section{A Brief Historical Overview}

Over the past ten years, Ontario has diverged very sharply from the performance of the rest of Canada (henceforth abbreviated as ROC, which is the total for Canada minus Ontario). Ontario has fallen behind both in labour productivity growth and in a host of other indicators such as employment growth and investment growth. This is due to the fact that Ontario's economy was the most open to international trade in general, and dependent in particular on exports of finished goods and services rather than raw commodities. It was therefore the most susceptible to both the sharp upward valuation of the Canadian dollar that began in 2003, and the deep recession among developed countries (and in particular the United States) that began in 2008.

Ontario had much more to lose than the rest of Canada, starting with a greater dependence on exports. The early 2000s were already weak because of the dot-com recession in the United States. Between 2002 and 2008, Ontario's international exports as a share of GDP fell by nearly 10 percentage points (Chart 1 ). In contrast, there was hardly any decline in the rest of Canada, where the rising dollar's effect was largely offset by rising international commodity prices. The recession reduced the export/GDP share by an additional 5 percentage points or so, causing

4 The author is indebted to Hugh Finnigan for providing the data, and to Qaizar Hussain and Hugh Finnigan at the Ontario Ministry of Finance for their earlier analysis of the data. 


\section{Table 1}

\section{Labour Productivity in Ontario and the Rest of Canada} (average growth rates, per cent)

\begin{tabular}{l|c|c|c} 
& 1984-2000 & 2000-2005 & 2005-2011 \\
\hline Business Sector & \multicolumn{3}{|c}{ Ontario } \\
\hline Service Sector & 1.3 & 0.8 & 0.0 \\
\hline Manufacturing & 1.2 & 1.6 & 0.5 \\
\hline & 2.6 & 0.1 & 0.1 \\
\hline Business Sector & \multicolumn{3}{|c}{ Rest of Canada (ROC) } \\
\hline Service Sector & 1.2 & 1.4 & 0.9 \\
\hline Manufacturing & 1.2 & 2.1 & 1.2 \\
\hline
\end{tabular}

Source: Statistics Canada, Canadian Productivity Accounts.

\section{Chart 1}

International Exports by Ontario and the Rest of Canada (per cent of nominal GDP)

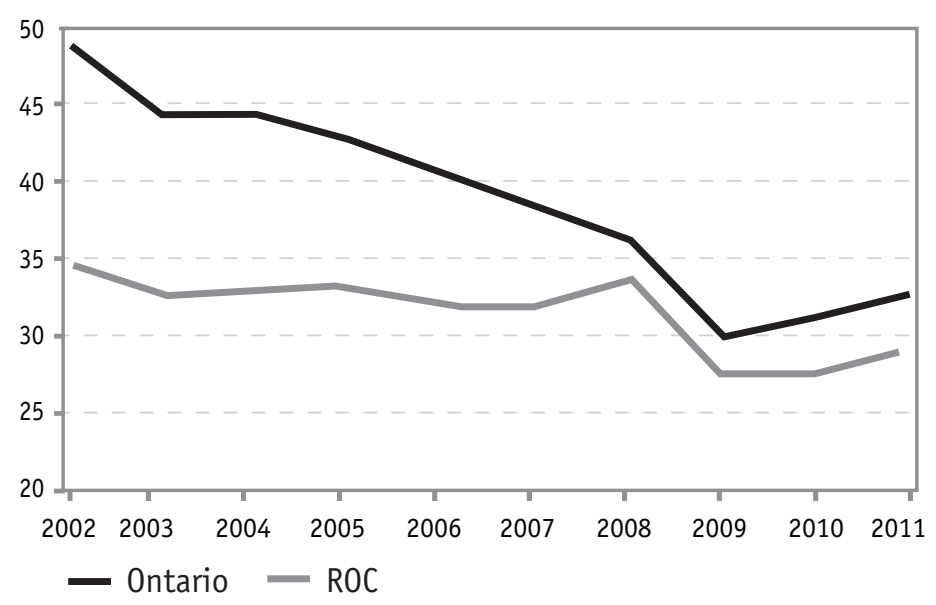

Source: Statistics Canada, Provincial Economic Accounts.

it to bottom out in 2009. Since then, there has been a modest recovery.

The loss in export sales fed through to weak overall demand and lost jobs. Export industries tend to have higher productivity levels than the average, and the loss of jobs in these industries forced workers to take jobs in much less productive sectors.

Table 1 summarizes labour productivity growth over three time periods for Ontario and the rest of Canada for the business sector, the service sector, and manufacturing. ${ }^{5}$

It can be seen that, prior to 2000, Ontario's performance was quite similar to that of the ROC. Ontario's business sector enjoyed moderate productivity growth, averaging 1.3 per cent per year from 1984 to 2000 .

In the six-year period from 2005 to 2011 , Ontario's business sector productivity growth was zero (Chart 2). While the ROC showed some weakness related to the recession, it was only modestly lower than its long-run historical average. When people speak about "Canada's abysmal productivity growth," which is a commonly seen phrase in business commentaries, they are talking (whether they know it or not) mainly about Ontario. ${ }^{6}$

Table 1 shows that manufacturing productivity growth was quite a bit stronger than service sector productivity growth in the 1984-2000 period. The service sector increased its share of total business sector output by 6 percentage points over this period. Not only did the service sector have lower productivity growth than manufacturing, but its level of output per hour worked was lower, bringing down the overall average as it increased its share of the economy. ${ }^{7}$ This is one example of how the composition of the economy can influence the overall average productivity growth rate.

Similarly, in the 2005-2011 period, overall business sector productivity growth was zero, despite non-zero growth in service sector pro-

5 The comparisons in this article are mainly between Ontario and the ROC. There are serious statistical problems in comparing productivity growth across countries, as noted by Diewert and Yu (2012).

6 Ontario's disproportionate contribution to the national decline has been noted by Sharpe and Thomson (2010), who appear to have coined this widely-quoted phrase. Their analysis covered the period up to 2007, and their conclusions were quite similar to those of this article.

7 As of 2011, real GDP per hour worked in Ontario in the service sector was $\$ 35.80$ overall, compared to $\$ 53.30$ in manufacturing. In addition, within services, much of the employment growth has been in sectors where the level of productivity is below the average for services as a whole. 
ductivity. In other words, the whole was less than the sum of its parts. This, too, is a function of the changing composition of output, as sectors with below-average levels of productivity increased their share of the total. The next section discussesthe effect of the distribution of output in more detail.

\section{How the Composition of Output Affects Aggregate Productivity}

The level of output per hour worked varies greatly across different sectors of the economy. This reflects the earnings of both the physical and human capital of the sector. Some sectors have a high GDP per hour worked, reflecting the high educational levels and incomes of their workers. Other sectors (such as mining and manufacturing) have a high GDP per hour worked because of the high capital-labour ratio, in spite of the relatively low human capital of their employees. ${ }^{8}$ In still others, such as food services, there are relatively low levels of both educational requirement (although, anecdotally, many servers have post-secondary education) and physical capital, leading to a low level of value added per hour worked.

Chart 3 shows the variation in labour productivity at the two-digit level of industries. Even at this level, there is a very large range, from GDP per hour worked of $\$ 120$ in utilities to less than $\$ 16$ in accommodation and food services. In 2011, Ontario had 446,000 workers in the latter sector, but only 46,000 in the utilities sector.

If we drill down further, we find even larger variations. At the three-digit level within the utilities sector, we find pipelines with GDP per hour worked of about $\$ 1,000$. In the finance and leasing sector, we find an average GDP per hour of $\$ 81$. However, if we go down to the four-digit

\section{Chart 2}

Index of Labour Productivity, Ontario, 2000-2011

(Real GDP per hour worked, 2000=100)

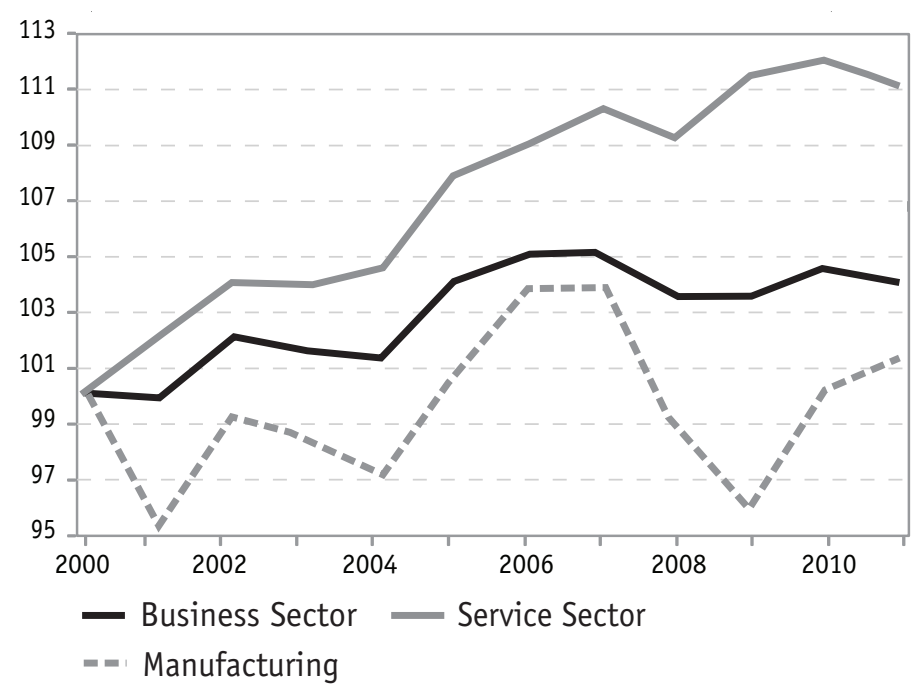

Source: Statistics Canada, Canadian Productivity Accounts.

\section{Chart 3}

\section{Labour Productivity in Ontario by Two-digit NAICS Sectors, 2011}

(Real GDP per hour worked)

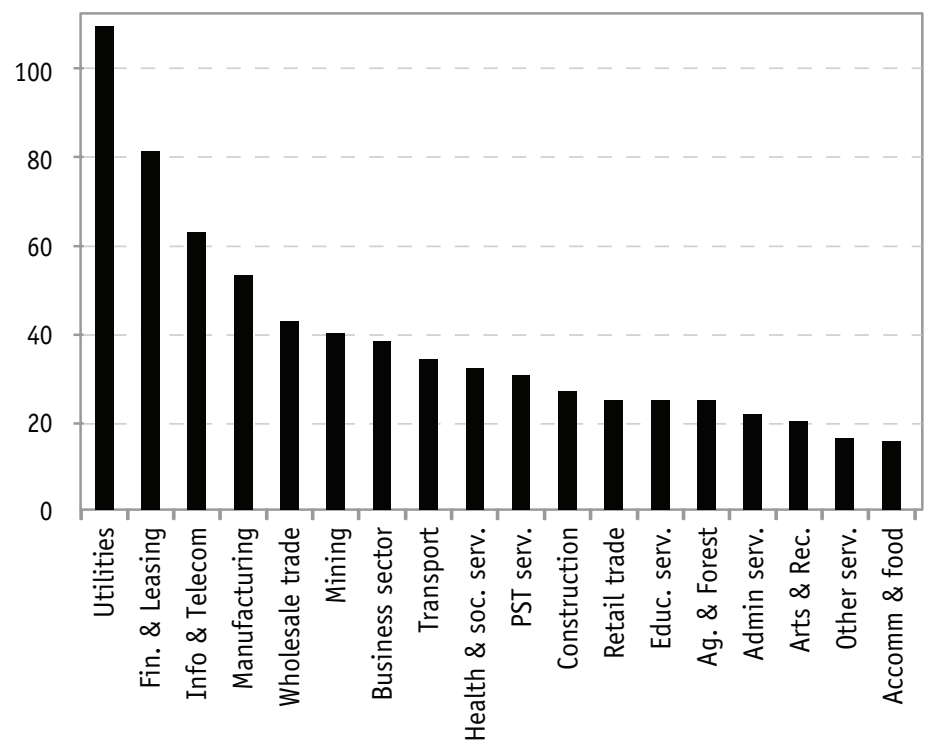

Source: Statistics Canada, Canadian Productivity Accounts.

8 The average wage in manufacturing is only $\$ 5$ per hour higher than in services, but the output per hour gap is about $\$ 17$, reflecting the higher capital/labour ratios in manufacturing. 
Table 2

A Simple Numerical Example Showing How a Change in the Composition of Output Can Affect Average Measured Productivity

\begin{tabular}{l|c|c|c|c|c} 
& \multicolumn{3}{|c|}{ Hours Worked } & \multirow{2}{*}{$\begin{array}{c}\text { Average Productivity } \\
\text { in the Economy } \\
\text { (Output per Hour } \\
\text { Worked) }\end{array}$} \\
\cline { 2 - 4 } & Food Services & Manufacturing & Total & Total GDP & $\$ 33$ \\
\hline 2005 & 1,000 & 1,000 & 2,000 & $\$ 66,000$ & $\$ 31.1$ \\
\hline 2006 & 1,000 & 800 & 1,800 & $\$ 56,000$ & $\$ 28.8$ \\
\hline 2007 & 1,000 & 600 & 1,600 & $\$ 46,000$ & \\
\hline
\end{tabular}

level within that sector, we find a range from $\$ 46$ in real estate services to $\$ 295$ in lessors of real estate (the companies that actually own the properties and earn the rent on them). These are very high levels of average productivity, but the marginal productivity from adding additional workers would be much lower than the average productivity. Likewise, the capital itself only has a high productivity if there is a use for it. Pipelines are very expensive, so if the pipeline earns its expected rate of return, the output per hour worked needed to maintain it will be very high. However, there would be no value in building a pipeline if there was no demand for its services, as it would earn a very low rate of return, and the marginal productivity would be far lower than the average productivity of existing pipelines.

In manufacturing, average GDP per hour worked was $\$ 53$ in 2011, but at the four-digit level we find a range from $\$ 22$ per hour in agricultural chemicals to $\$ 133$ in automobile assembly. What is even more peculiar is that several years ago the level for agricultural chemicals was over $\$ 80$ per hour, and for auto assembly it was over $\$ 170$ per hour.

Even the four-digit level is highly aggregated, and obscures the considerable differences that can exist between one company and another. Different companies that fall into a category can be vastly different in what they produce and how they do it. Their productivity will fall if they are operating at below capacity because of weak demand, and because they have to keep on managerial and security employees even when the plant is idle.

A Hypothetical Example: Assume an economy that consists of just two sectors, food services and manufacturing. Output per hour worked is $\$ 16$ in food services, and $\$ 50$ in manufacturing. As the number of hours worked in manufacturing declines due to lower exports, aggregate productivity (output per hour worked) declines in the economy, as shown in Table 2. In this example, a large decline in aggregate measured productivity occurs, even though there has been no actual change in productivity at the industry level.

\section{The Effect of Export Demand on Output Composition}

Ontario's exporting industries, such as auto manufacturing, with output per hour of well over $\$ 100$, are among the ones that have the highest output per hour. By contrast, local service producing firms and manufacturers that serve the domestic market tend to have lower productivity. The decline in exports has reduced the output of some of the higher-productivity sectors in the Ontario economy. This development would have a negative impact on average labour productivity for the reasons just discussed, even if there was no impact on productivity within any individual industry.

In reality, even productivity at the plant level is often adversely affected, as some of the remaining operations would be operating at a 
smaller scale, thereby spreading overhead costs over a smaller amount of production.

Many large operations with high absolute levels of GDP per hour worked (such as major steel mills at the former Stelco) were shut down, not being able to compete due to the sudden appreciation of the Canadian dollar. This leaves a larger share of what is classed as manufacturing in less efficient firms that serve local markets, such as small firms processing scrap metal. Other examples include small-scale specialty food manufacturing and custom furniture makers.

It may seem paradoxical that more productive operations fail, while less productive ones remain, but there is considerable segmentation in markets. Some products have a substantial service component (or other characteristics, such as being perishable), and gain an advantage from being closer to markets. Their price elasticity of demand is therefore relatively low, and they can survive despite having lower output per hour worked. Other products which are very generic have to compete in global markets purely on price, and their price elasticity of demand is very high.

The tendency towards smaller-scale operations over the past several years is evident in the data on Ontario employment by class and size of establishment. The employment changes in the Ontario economy over the past several years have been in the direction of smaller scale and lower efficiency.

GDP per worker in unincorporated businesses is less than half of the business sector average. If the new participants in that sector since 2007 could instead have been employed at the economy-wide average, that by itself would have boosted real GDP by about half a per cent. That is just the tip of the iceberg, however, as these participants happen to fall into a class of workers for which we have specific data. Overall, there has been a general shift throughout the economy towards firms of smaller size and less efficient scale.

A very detailed study of plant-level productivity by Baldwin and Yan (2010) looked specifically at manufacturing in the period from 2000 to 2006. The authors found that the higher dollar led to a shift away from export orientation, with a resultant weakening of productivity growth: "Export-market participants gain more in productivity growth from currency depreciation than non-participants... the dramatic increase in the value of the Canadian dollar during the post-2000 period almost completely offset the advantages enjoyed by export-market participants. Our counterfactual exercise shows that fluctuations in real exchange rates explain almost all the shifts in productivity growth gaps between export-market participants and nonparticipants in this latter period."

Between 2003 and 2011, total employment and hours worked in manufacturing in Ontario fell by almost 30 per cent (Chart 4), but the decline was greatest in the firms with the most employees, and hence the firms that would be expected to have the greatest economies of scale. Table 3 shows the share of manufacturing employees by firm size. In Ontario, fewer than 20 per cent of manufacturing workers in 2011 were in firms with more than 500 employees. By comparison, about 50 per cent work for firms of that size in the United States.

The decline in manufacturing productivity growth in Ontario was particularly large, from an average annual growth of 2.6 per cent per year prior to 2000 , to near-zero after that. It appears that this can be fully explained by the decline in demand for Ontario's manufacturing output. It is possible to estimate the correlation between manufacturing productivity growth and output growth over the historical period with regression analysis, as described in a later section. As discussed there, the relationship is quite stable, finding nearly identical coefficients 


\section{Chart 4}

\section{Total Hours Worked in Manufacturing}

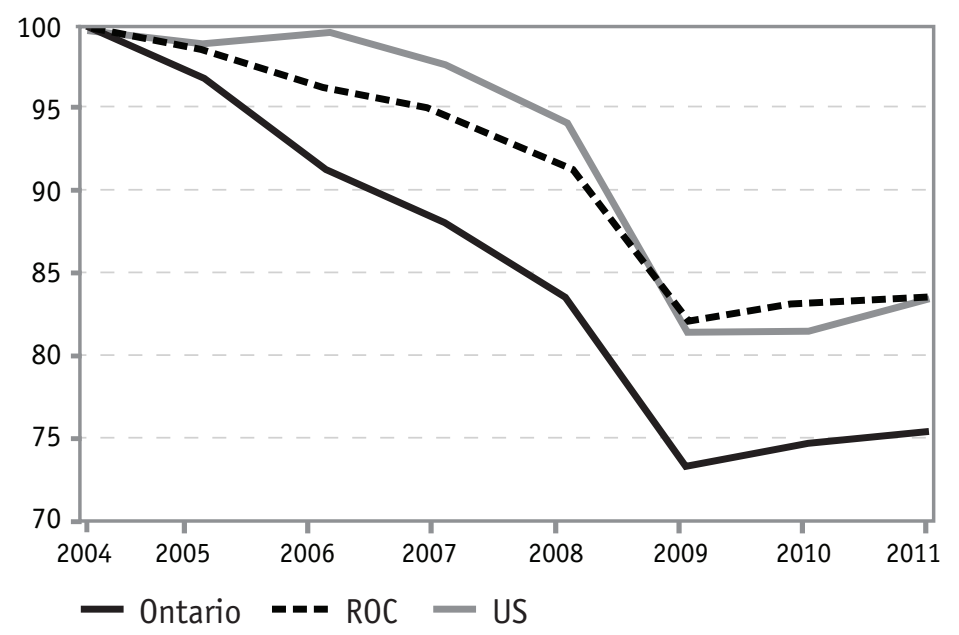

Source: Statistics Canada, Canadian Productivity Accounts and BEA.

Table 3

\section{Distribution of Manufacturing Employees in Ontario by}

Firm Size, 2003-2011

\begin{tabular}{l|c|c|c} 
& $\begin{array}{c}\text { Fewer than } 100 \\
\text { Employees }\end{array}$ & $\mathbf{1 0 0}$ to $\mathbf{5 0 0}$ & More than $\mathbf{5 0 0}$ \\
\hline 2003 & 40.5 & 37.2 & 22.3 \\
\hline 2004 & 40.2 & 38.6 & 21.2 \\
\hline 2005 & 41.4 & 38.2 & 20.4 \\
\hline 2006 & 42.7 & 35.5 & 21.8 \\
\hline 2007 & 42.5 & 35.7 & 21.8 \\
\hline 2008 & 44.4 & 35.6 & 20.1 \\
\hline 2010 & 49.0 & 33.8 & 17.2 \\
\hline 2011 & 47.1 & 35.0 & 17.8 \\
\hline
\end{tabular}

Source: Statistics Canada.

in periods of output growth and output decline. This suggests that productivity growth in manufacturing rises about 0.6 per cent with each 1 per cent increase in output growth.

This coefficient is applied in Table 5 to calculate how much higher Ontario's manufacturing productivity growth might have been with higher output matching that of the United
States or the ROC. ${ }^{9}$ Interestingly, the result is that Ontario would have closely matched productivity growth in those other jurisdictions, which implies that Ontario's weak manufacturing productivity growth is fully explained by its weak output growth. That, in turn, is substantially explained by the high Canadian dollar. The other provinces largely managed to avoid this situation. They export less of their manufactured products, and more of what they produce is of a specialized nature related to their resource industries.

The next section will seek to confirm these macroeconomic estimates by looking at how changes in the micro structure of production contributed to changes at the aggregate level.

\section{Why Has Service Sector Productivity Growth Underperformed?}

As seen in Table 1, Ontario also underperformed compared to the rest of Canada in service sector productivity growth, which was positive but weak in Ontario. Table 4 provides the details for the 2005-2011 period.

The most important service sector industry for Ontario is financial services, representing 29 per cent of services output. Ontario's productivity growth slightly outperformed the ROC average for this industry.

The next most important industries are wholesale and retail trade, which together comprise 24 per cent of service sector output. For these industries, Ontario's productivity growth was reasonably good, but substantially lower than the very strong ROC average growth. There does not appear to be much of a difference in trend between Ontario and the rest of Canada in this sector. The relative levels of productivity were not materially different in 2011 than they were ten or fifteen years earlier,

9 Table 5 covers the rates of change from 2005 to 2011, as data on US manufacturing value added for previous years are not available from the Bureau of Economic Analysis. 


\section{Table 4}

Labour Productivity Growth in Services in Ontario and the Rest of Canada, 2005-2011

\begin{tabular}{|c|c|c|c|c|}
\hline \multirow{2}{*}{$\begin{array}{l}\text { NAICS } \\
\text { code }\end{array}$} & & \multirow{2}{*}{$\begin{array}{l}\% \text { Share of } \\
\text { Ontario } \\
\text { Services GDP } \\
\text { in } 2011\end{array}$} & \multicolumn{2}{|c|}{$\begin{array}{c}2005-2011 \\
\text { (avg. annual growth rates, \%) }\end{array}$} \\
\hline & & & Ontario & Rest of Canada \\
\hline & Total & 100.0 & 0.5 & 1.6 \\
\hline 410 & Wholesale Trade & 12.4 & 1.7 & 3.1 \\
\hline $4 \mathrm{~A} 0$ & Retail Trade & 11.7 & 1.5 & 2.8 \\
\hline 484 & Truck Transportation & 2.3 & -0.9 & 3.1 \\
\hline 485 & Transit and Ground Passenger Transportation & 1.0 & 1.0 & 0.7 \\
\hline 486 & Pipeline Transportation & 0.3 & 3.7 & 2.2 \\
\hline $48 \mathrm{~A}$ & 0ther Transportation & 2.8 & 2.4 & 2.0 \\
\hline 493 & Warehousing and Storage & 0.3 & -2.3 & -0.7 \\
\hline $49 \mathrm{~A}$ & Postal Service and Couriers and Messengers & 1.2 & -1.0 & 1.3 \\
\hline 512 & Motion picture and sound recording industries & 0.5 & $x$ & $-0.5^{*}$ \\
\hline $51 \mathrm{~B}$ & $\begin{array}{l}\text { Publishing, Broadcasting, Telecommunications and Other } \\
\text { Information Services }\end{array}$ & 6.9 & $x$ & $0.0^{*}$ \\
\hline 541 & Professional, Scientific and Technical Services & 11.3 & -1.3 & 0.1 \\
\hline 561 & Administrative and Support Services & 4.9 & -1.0 & 0.1 \\
\hline 562 & Waste Management and Remediation Services & 0.7 & -0.5 & 0.5 \\
\hline $5 \mathrm{AO}$ & $\begin{array}{l}\text { Finance, Insurance, Real Estate and Rental and Leasing } \\
\text { (excluding owner occupied dwellings) }\end{array}$ & 29.3 & 1.7 & 1.3 \\
\hline 610 & Educational Services & 0.5 & 1.0 & -1.3 \\
\hline 620 & Health Care and Social Assistance & 5.4 & -0.6 & -0.8 \\
\hline 710 & Arts, Entertainment and Recreation & 1.5 & -1.3 & -1.4 \\
\hline$\underline{720}$ & Accommodation and Food Services & 3.9 & 1.5 & -0.1 \\
\hline 811 & Repair and Maintenance & 1.2 & -1.3 & 1.2 \\
\hline 813 & Civic and Professional Organizations & 0.5 & -2.0 & -0.4 \\
\hline $81 \mathrm{~A}$ & Personal, Household and Laundry Services & 1.5 & -1.9 & -0.4 \\
\hline
\end{tabular}

$X=$ unavailable due to confidentiality; ${ }^{*}$ denotes value for all of Canada, as ROC cannot be calculated.

Source: Statistics Canada, Canadian Productivity Accounts.

despite the recent stronger growth in the ROC. The differences in the recent growth rates likely reflect the weaker income growth and resulting weaker sales growth in Ontario rather than any fundamental differences. Over the 2005-2011 period, the growth rate of combined nominal retail and wholesale sales in ROC was 27.0 per cent, compared to only 16.4 per cent in Ontario. In addition, one of the activities that people who become self-employed do is small scale, low productivity retailing, and self-employment was the largest area of employment growth in Ontario in this period (Table 5). ${ }^{10}$

There are a number of service sector industries that experienced negative productivity growth. The most significant of these was the professional, scientific and technical services area. In spite of its grand-sounding name, it is a miscellaneous category with over 500,000 jobs that includes low-paying occupations such as bookkeeping services. ${ }^{11}$ A surplus of workers willing to take low-paying jobs may have boosted employ-

10 Over the 2005-2011 period, self-employed persons with no employees increased 17.4 per cent in Ontario, compared to only 7.8 per cent in the ROC. Sadly, this was Ontario's only "booming" area of employment.

11 About 36 per cent of the workers in professional, scientific and technical services were self-employed in 2011, which is up by about 3 percentage points since 2007 (Cansim Table 282-0011). This is consistent with the view that people who cannot find paid jobs move into fields where they have self-employment opportunities. Especially at first, they often have poor earnings, dragging down the average productivity of the sector. 


\section{Table 5}

Employment in Ontario by Type, 2007 and 2011

\begin{tabular}{l|c|c|c}
\multirow{2}{*}{} & \multicolumn{2}{|c|}{ Thousands of Jobs } & \multirow{2}{*}{$\begin{array}{c}\text { Per Cent } \\
\text { Change }\end{array}$} \\
\cline { 2 - 3 } & $\mathbf{2 0 0 7}$ & $\mathbf{2 0 1 1}$ & \\
\hline Total business sector employment & 5365 & 5388 & 0.4 \\
\hline $\begin{array}{l}\text { Total employees, firms with 500+ } \\
\text { employees }\end{array}$ & 547 & $\mathbf{4 7 2}$ & -13.7 \\
\hline Self-employed with employees & 317 & 309 & -2.6 \\
\hline Self-employed without employees & 653 & 719 & 10.1 \\
\hline
\end{tabular}

Source: Statistics Canada, Labour Force Statistics.

\section{Chart 5}

\section{Change in Hours Worked by Two-digit NAICS Sectors in Ontario, 2005-2011}

(thousands of hours worked)

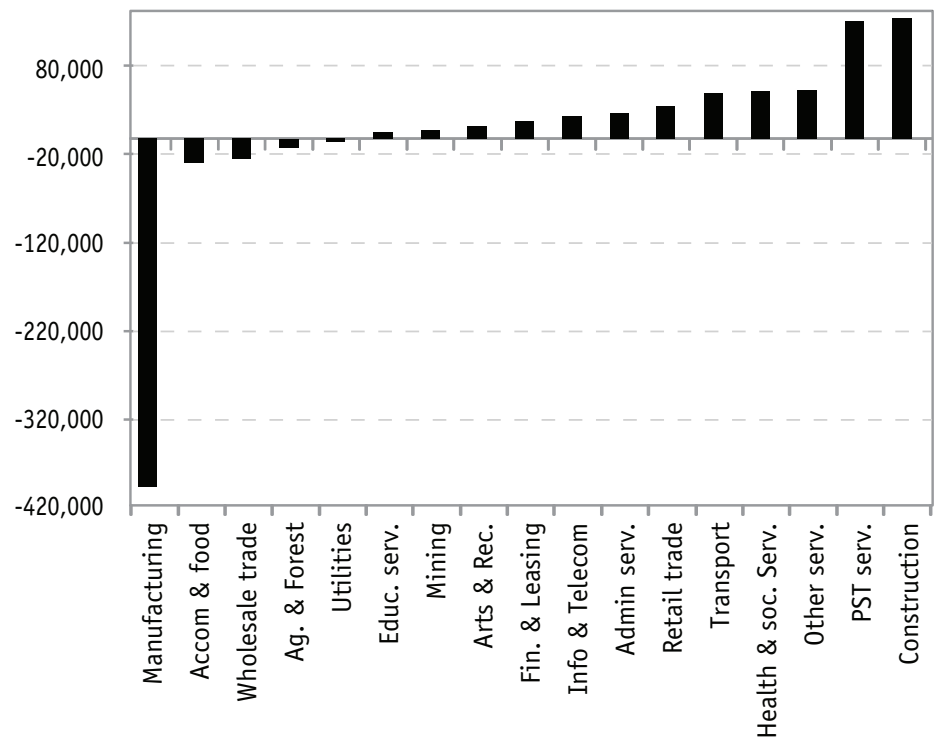

Source: Statistics Canada, Canadian Productivity Accounts.

ment in the lower-productivity segments of this classification. As will be discussed in the next section, absolute declines in productivity in particular sectors probably indicate a change in composition. This is often the result of weak demand for the higher productivity activities, which forces people to move into lower productivity ones for the lack of any better alternative.

\section{Three-Digit NAICS Sectoral Decomposition of the Weakness in Ontario's Productivity}

This section looks at variations in the economy using the three-digit NAICS code level, which breaks out about 50 business sector industries. ${ }^{12}$ The purpose is to estimate the total impact of detailed compositional change and other factors in dragging down aggregate productivity growth in Ontario.

Two types of counterfactual analysis will be undertaken here. The first looks at how productivity would have differed if the growth in hours of employment in all sectors had been the same. This is intended to control for the effect of changes in the composition of the economy. The second analysis will take into account the observation that many of the three-digit sectors had substantial declines in the level of productivity. The reason for these declines is not fully understood, but it probably reflects cyclical drops due to lost economies of scale, excess capacity, and possibly also a shift of composition within the three-digit sector.

The most salient compositional shift is that employment in manufacturing dropped sharply as a share of total employment, and its average productivity is higher than the economy-wide average. Some of the strongest growth areas in employment were in parts of the service sector that have relatively low productivity.

The analysis will be carried out for changes in employment from 2005 to 2011, which was noted in Table 1 as being a period when Ontario's business sector had zero overall productivity growth.

Chart 5 highlights the wide variation in the change of hours worked in Ontario at the twodigit NAICS level. It shows the change in hours worked in terms of absolute numbers, rather

12 In principle, there are 51 categories at the three-digit level of the Productivity Accounts. However, at this level, four of them are suppressed by Statistics Canada for Ontario in order to protect confidentiality, thereby leaving 47 categories for the analysis. 


\section{Table 6}

Counterfactuals: How Much Would Ontario's Manufacturing Labour Productivity Growth Have Increased if Ontario's Output Growth had Matched that of the Rest of Canada or the United States?

\begin{tabular}{l|c|c}
\multicolumn{1}{c|}{$\mathbf{2 0 0 5 - 2 0 1 1}$} & $\begin{array}{c}\text { Output, } \\
\text { (average annual change, \%) }\end{array}$ & $\begin{array}{c}\text { Labour Productivity, } \\
\text { (average annual change, \%) }\end{array}$ \\
\hline Rest of Canada & -0.3 & 2.2 \\
\hline United States & 0.6 & 3.3 \\
\hline Ontario & -3.4 & 0.6 \\
\hline If Ontario had matched ROC output growth & $\begin{array}{c}\text { add 3.1 to Ontario's output } \\
\text { to raise it to -0.3 }\end{array}$ & $0.6+0.64^{\star} 3.1=2.6$ \\
\hline If Ontario had matched US output growth & $\begin{array}{c}\text { add 4.0 to Ontario's output } \\
\text { to raise it to 0.6 }\end{array}$ & $0.6+0.64^{*} 4.0=3.2$ \\
\hline
\end{tabular}

\section{Table 7}

\section{Alternative Scenarios of Ontario Business Sector Productivity Growth, Based on Reversing Adverse Changes at the Three-digit NAICS Level}

\begin{tabular}{l|c|c} 
& $\begin{array}{c}\text { GDP in 2011, \$billions } \\
\text { (2002 constant dollars) }\end{array}$ & $\begin{array}{c}\text { Implied Annual } \\
\text { Average \% Productivity } \\
\text { Growth, 2006 to 2011 }\end{array}$ \\
\hline Actual business sector GDP in 2011 & 347.1 & 0.0 \\
\hline $\begin{array}{l}\text { Hypothetical GDP if all sectors had the same per cent change in } \\
\text { hours worked from 2006 to 2011 (total hours remaining the same } \\
\text { for the whole economy) }\end{array}$ & 359.6 & 0.6 \\
\hline $\begin{array}{l}\text { Hypothetical GDP if no sector had suffered a decline in 2011 } \\
\text { relative to its previous maximum absolute level of productivity }\end{array}$ & 371.7 & 1.1 \\
\hline Combined effect of both of the above adjustments & 386.0 & 1.8 \\
\hline
\end{tabular}

than percentage change, as it is the absolute number that determines its weight in the impact on the overall productivity outcome. For example, mining is a relatively high productivity industry that had a strong per cent increase in hours worked. However, it started from a small base, and a large per cent change represents a relatively small number of jobs and a small amount of GDP. Therefore, it only had a small impact on the overall outcome. There are too many industries at the three-digit level to easily fit into a chart, but the actual analysis will be carried out at the three-digit level. At the threedigit level, the outcome is worsened by the fact that the largest loss in hours in manufacturing was in auto assembly, which is also the sub-sec- tor of manufacturing with the highest level of productivity.

The results of two types of recalculation are depicted in Table 7 above. The first one rebalances the hours worked to calculate the level of GDP that would have existed in 2011 if all sectors had hours growing at the same rate.

The second recalculation makes a more radical alteration. It recognizes that even at the disaggregation provided at the three-digit level, ${ }^{13}$ much of the change in composition is hidden. One of the startling features of the sectoral productivity data is that, for a number of industries, the level of productivity in 2011 is well below the peak. The low average productivity growth that occurred was not the

13 The experimental Productivity Accounts also include a four digit NAICS level. This provides a theoretical set of 95 categories, of which 11 are suppressed for Ontario due to confidentiality. This makes analysis at that level problematic, as a larger proportion of the economy is missing. 


\section{Table 8}

\section{Manufacturing Productivity Levels in Ontario in 2011 Compared to the Peak in the Previous Decade}

\begin{tabular}{l|l|c} 
NAICS code & Name & $\begin{array}{c}\text { Level of Productivity in 2011 } \\
\text { Relative to Previous Peak } \\
\text { (per cent difference) }\end{array}$ \\
\hline 311 & Food Manufacturing & -3.1 \\
\hline 312 & Beverage and Tobacco Product Manufacturing & -25.4 \\
\hline $31 A$ & Textile and Textile Product Mills & -15.1 \\
\hline 315 & Clothing Manufacturing & -22.1 \\
\hline 316 & Leather and Allied Product Manufacturing & -4.6 \\
\hline 321 & Wood Product Manufacturing & -9.1 \\
\hline 322 & Paper Manufacturing & -6.1 \\
\hline 325 & Printing and Related Support Activities & -18.2 \\
\hline 326 & Chemical Manufacturing & -22.1 \\
\hline 327 & Plastics and Rubber Products Manufacturing & 0.0 \\
\hline 331 & Non-Metallic Mineral Product Manufacturing & -7.0 \\
\hline 332 & Primary Metal Manufacturing & -12.7 \\
\hline 333 & Fabricated Metal Products Manufacturing & -8.4 \\
\hline 334 & Machinery Manufacturing & -0.6 \\
\hline 335 & Computer and Electronic Product Manufacturing & 0.0 \\
\hline 336 & Electrical Equipment, Appliance and Component Manufacturing & -25.6 \\
\hline 337 & Transportation Equipment Manufacturing & -9.9 \\
\hline 339 & Furniture and Related Product Manufacturing & -23.1 \\
\hline $3 \mathrm{~A}$ & Miscellaneous Manufacturing & -10.6 \\
\hline & Total Manufacturing & -2.2 \\
\hline
\end{tabular}

Souce: Author's calculations, based on Statistics Canada, Canadian Productivity Accounts.

result of all industries growing together at the same weak rate. Rather, it is the average of industries that had positive productivity growth, and others that had large declines not just in growth rate but in level. Industries with substantial absolute declines in productivity are especially prevalent in manufacturing, as seen in Table 8. Out of 19 three-digit NAICS categories in manufacturing, all but two were below their previous peak level of productivity in 2011. ${ }^{14}$ In some cases they were far below their peaks, no doubt indicating that some major facilities that had high levels of productivity had been completely shut down. ${ }^{15}$

If weak productivity growth is meaningful as a concept, it must refer to sectors that are not investing enough, or are not innovative enough. These factors would reduce the growth rate, but they would not ordinarily cause a drop in the level far below what had been previously reached. ${ }^{16}$ Mere lack of ambition or effort as the causal factors would imply a rate of zero as the floor for productivity growth in each sector. Where sectors are showing large drops, it may

14 It is true that in the process of Schumpeterian 'creative destruction', certain industries will be undergoing decline even in good economic times. However, 2011 was clearly atypical. Only two out of 19 industries were not below their previous peak, with an average (unweighted) ratio of 0.85 (2011 productivity level divided by the previous peak level). By comparison, in 1999 it was eight out of 19, with an average ratio of 0.92. About half the 19 industries had their peak year of productivity in the 2005-07 period, while the other half peaked as far back as 2000-2003.

15 I have omitted petroleum and coal products (code 324) from the table, pending the verification of a data anomaly. This industry's productivity in 2011 displays a remarkable 66 per cent decline from its peak. There was one major refinery closure in 2005 , but this does not appear to be sufficient to explain such a large decline. 
be partly because there are unfortunate compositional changes going on within those sectors that we cannot discern from the data. For example, large companies that formerly competed in the export market and had economies of scale have gone out of business, leaving a residue of smaller firms serving the domestic market. The latter survive despite their small scale and inefficiency (from a global perspective) due to the presence of a particular service niche that enables them to operate.

The sectors that are showing absolute declines in the level of productivity account for most of the decline in overall productivity growth. The second recalculation in Table 8 controls for this factor. It shows what the level of GDP in Ontario would have been in 2011 if the sectors for which declining productivity is found in the data had instead stayed at the previous highest level that they had attained before the decline. When both of these calculations are combined, we find that the level would be 11.2 per cent higher than the actual. That is, the zero productivity change actually recorded in the 2006 to 2011 period would instead have been 1.8 per cent per year. This change is higher than the historical average, but not out of the range of variation for a period of six years. ${ }^{17}$ What this highlights is that there were some sectors in which companies were making considerable efforts, in the face of adversity, to achieve productivity growth.

The second row in Table 7 reflects the effect of the most obvious form of compositional shift based on the evidence of changes in the relative amount of work done in different sectors. The share of work in sectors with below average productivity has increased, and this accounted for a reduction of 0.6 per cent per year in productivity growth. However, as discussed above, that does not necessarily tell us the whole story about composition. One factor that may explain why certain three-digit NAICS industries had absolute drops in their level of productivity is that a larger share of their output is directed towards local demand (e.g. the customized small-scale operations with a service component, such as cabinet makers, as opposed to large scale furniture manufacturing). These operations tend to be more labour-intensive and have lower productivity. However, the lack of data on productity levels broken down by firm size and by industry means that the importance of this factor is not known.

\section{The Relationship between Output and Productivity Growth in Manufacturing: Regression Analysis}

This section uses regression analysis to examine the relationship between output and productivity growth in manufacturing in Ontario. The dependent variable is the year-to-year per cent change in real value added per hour worked, and the explanatory variable is the per cent change in value added. A pooled cross-section regression was run using data for 19 three-digit manufacturing subsectors.

In this type of specification, there is a risk of endogeneity that can bias the results and produce a spurious correlation. Did weak output growth in the post-2000 period cause weak productivity growth? Or was there some exogenous negative shock to Ontario's technology or work attitudes that caused weak productivity growth, which in turn made Ontario companies unable

16 One could think of some extreme examples where productivity would drop due to a lack of investment. For example, this might happen if a company hired more workers without adding more capital, and forced existing workers to share their equipment with new workers. Such behaviour is likely to be rare, particularly in manufacturing, where there has been a large decline in total employment.

17 For example, the average annual productivity growth in the Ontario business sector for the six years ending in 2002 was 2.6 per cent. 
Table 9

Regression Estimates for the Effect of Demand Growth on Labour Productivity Growth in Ontario's Three-digit NAICS Manufacturing Sectors

\begin{tabular}{l|c|c|c} 
Regression Method & \multicolumn{2}{|c|}{ OLS } & Instrumental Variables \\
\hline Sample period (annual data) & 1985 to 1999 & 2000 to 2011 & 1985 to 2011 \\
\hline Total panel (balanced) observations & 300 & 240 & 540 \\
\hline Constant & $1.1^{*}(1.8)$ & $2.0^{* * *}(4.2)$ & $1.6^{* * *}(3.4)$ \\
\hline $\begin{array}{l}\text { Coefficient on change in sector's } \\
\text { output growth }\end{array}$ & $0.68^{* * *}(10.2)$ & $0.64^{* * *}(14.8)$ & $0.45^{* * *}(5.0)$ \\
\hline Adjusted R-squared & 0.26 & 0.48 & 0.04 \\
\hline Durbin-Watson stat & 2.44 & 2.25 & 2.34 \\
\hline
\end{tabular}

t-statistics are in parentheses. ${ }^{*}, * *$, and $* * *$ denote $10 \%, 5 \%$, and $1 \%$ significance levels, respectively.

to compete, and led to reduced productivity growth?

There are different ways to address this problem, as this is a situation where extrinsic knowledge provides a ready answer. There were two obvious and very large negative demand shocks in the post-2000 period: a more than 60 per cent appreciation in the value of the Canadian dollar, and the worst recession in the industrialized world since the 1930s. In this context, any special factors originating in Ontario that might have independently reduced productivity growth must be very minor by comparison.

In the regressions shown in Table 9, the sample is split into two parts. The first regression covers the period from 1985 to 1999 , and the second one from 2000 to 2011. The former corresponds to a period of strong positive output growth, while the latter corresponds mainly to falling output in manufacturing. In spite of the marked difference between the periods, the coefficient on the output variable is almost identical. This gives us considerable confidence that there is a stable structural relationship between productivity growth and output growth. If there was a spurious relationship significantly biased by endogeneity, the very different val- ues of the dependent variable in the two subperiods would likely have resulted in quite different (random) results.

The most rigorous way to deal with this problem is two-stage regression using instrumental variables. This approach was also tried, and it confirms the results. Using just two instrumental variables, a statistically significant coefficient of $0.45(\mathrm{t}=5.0)$ was obtained, indicating that productivity changes 0.45 per cent for each percentage point change in output. ${ }^{18}$ The two instrumental variables were the deviation of the exchange rate from purchasing power parity, and the rate of change in aggregate US manufacturing output. As this is a panel regression with productivity growth in 20 different sectors being used as the dependent variable, the instrumental variable would ideally have consisted of data for those same specific 20 sectors in the United States. Unfortunately, matching data were unavailable. Nevertheless, it is likely that the coefficient in the two-stage regression would have moved upward with better data, and therefore an estimate near 0.6 (used in Table 6) is likely the best one.

At the aggregate level, growth in manufacturing output in Ontario is quite well-explained by both US growth and the deviation of the

18 It will be noticed that the R-squared is very low. As pointed out by Wooldridge (2013: 523), "Unlike in the case of OLS, the R-squared from IV estimation can be negative because SSR for IV can actually be larger than SST. Although it does not really hurt to report the R-squared for IV estimation, it is not very useful, either." 
exchange rate from its purchasing power parity value. It can be seen in Chart 6 that the peaks and troughs of the rate of change of Ontario's manufacturing output growth roughly correspond with US real GDP growth, while manufacturing output is far more volatile.

As Chart 7 shows, however, there is a much closer correlation between Ontario manufacturing output and US manufacturing output, which in turn reflects a close integration of the sectors.

Table 10 reports regression results, where the dependent variable is the annual per cent change in real value added in manufacturing, either in Ontario or the ROC.

The first explanatory variable is the annual percentage change in US manufacturing output. The other explanatory variable is the change from the previous year in the ratio of the actual exchange rate to its PPP value (from the OECD). A rising value implies overvaluation. A distributed lag from $\mathrm{t}(-1)$ to $(\mathrm{t}-4)$ was found to provide the best fit.

The high coefficient on US manufacturing indicates the high degree of integration of Ontario with the US economy under the Canada-US Free Trade Agreement.

Experiments with alternative distributed lag structures on the exchange rate found that the best fit was obtained by only two lags, $t-1$ and $t-$ 4 , which yields the favourable outcome that the adjustment to the exchange rate is completed after four years. If this can be relied on, it would imply that Ontario is over the worst of the adjustment. The effect of the exchange rate on the rate of change of output has almost completed its adjustment. Note that the dependent variable is the rate of change of manufacturing output. A negative rate of change cumulates to a lower level. This implies a permanent loss in the level of output as long as the exchange rate remains at its elevated level. ${ }^{19}$

\section{Chart 6}

\section{Change in Ontario's Manufacturing Output and US Total Economy Output}

(per cent change)

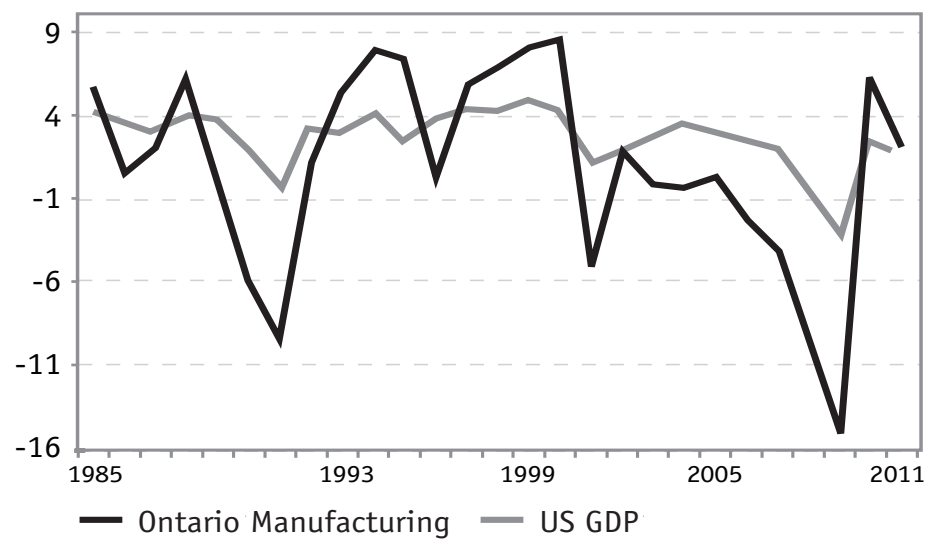

Source: Statistics Canada and BEA.

\section{Chart 7}

\section{Change in Manufacturing Output in Ontario and the United States}

(per cent change)

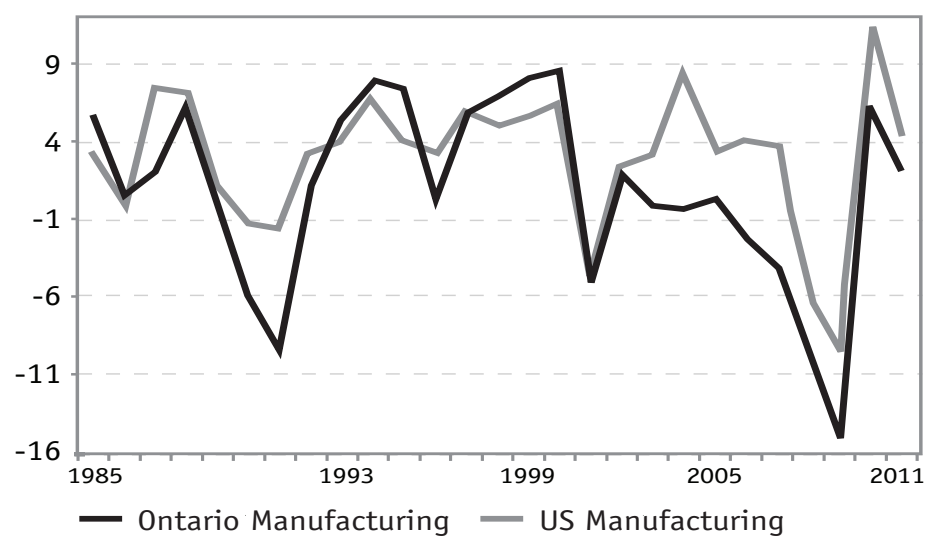

Source: Statistics Canada and BEA.

The coefficient on US growth is slightly larger than on the exchange rate, but that does not tell the whole story in terms of the magnitude of impact. The standard deviation of the US growth rate was only 4.5 , while the standard

19 A high degree of temporal stability was found. When the regression was estimated over the shorter sample from 1985 to 2001, which leaves out the latest upward trend of the exchange rate, the sum of coefficients was little changed, at -0.73 . However, the t-stat was also lower, at -2.6. 


\section{Table 10}

Regression Estimates Explaining the Growth of Manufacturing Output in Ontario versus the Rest of Canada

\begin{tabular}{l|c|c} 
& Ontario & Rest of Canada \\
\hline Sample period (annual data) & 1985 to 2011 & 1985 to 2011 \\
\hline Constant & $-1.2^{*}(-1.9)$ & $0.2(0.3)$ \\
\hline $\begin{array}{l}\text { Coefficient on annual per cent change in US } \\
\text { manufacturing output }\end{array}$ & $0.86^{* * *}(6.8)$ & $0.71^{* *}(5.3)$ \\
\hline $\begin{array}{l}\text { Coefficient on change from the previous year } \\
\text { in the ratio of the actual exchange rate to its }\end{array}$ & $-0.77^{* * *}(-4.8)$ & $-0.28^{*}(-1.6)$ \\
$\begin{array}{l}\text { PPP value (sum over a four period } \\
\text { distributed lag) }\end{array}$ & & \\
\hline Adjusted R-squared & 0.82 & 0.63 \\
\hline Durbin-Watson stat & 1.87 & 1.54 \\
\hline
\end{tabular}

t-statistics are in parentheses. ${ }^{*},{ }^{* *}$, and ${ }^{* * *}$ denote $10 \%, 5 \%$, and $1 \%$ significance levels, respectively.

deviation of the exchange rate variable was 6 over the historical sample period. The implication of the distributed lag formulation is that the exchange rate takes about four years to be fully passed through, but the bulk of the impact is felt within three years.

It is interesting to compare the situation of manufacturing between Ontario and the ROC. The coefficient on US growth is almost the same. While the ROC provinces export products related to natural resources, the demand for these products appears to be highly correlated with the US manufacturing cycle.

What is remarkably different is the exchange rate, which is just barely statistically significant in explaining manufacturing output in the ROC, and has a much lower impact. This does not change even when a shorter sample period is used, leaving out the latest upsurge of the exchange rate. The sum of coefficients on the exchange rate distributed lag is -0.77 for Ontario, compared to only -0.28 for the ROC.

These findings probably reflect the greater reliance of the ROC on exports of natural resource commodities, whose prices are set internationally in US dollars, and which tend to be correlated with the exchange rate. Much of what is classed as manufacturing in those provinces consists of either processing those commodities, or providing inputs into the commodity production. Strong commodity prices encourage natural resource production in those provinces, as well as resource-related manufacturing activities.

\section{Conclusions and Directions for Further Research}

The analysis in this article has found that the productivity behaviour of the sub-sectors of the Ontario economy is very diverse. There is not a single low rate of labour productivity growth that is found uniformly throughout the Ontario economy, like a pervasive miasma of mediocrity.

The aggregate productivity growth rate for Ontario's business sector averaged zero over the past six years, but this does not mean that all industries experienced zero productivity growth. A few had quite strong growth, while others suffered absolute declines in their productivity level.

By and large, it is possible to explain the overall weak productivity with reference to weak demand growth. Weak demand for Ontario's production has resulted in various adverse effects on productivity. It has led to lower capacity utilization, and to overhead expenses being spread over a smaller base. It has also led to people who have lost jobs in higher productivity sectors to shift into whatever jobs they could get, and these jobs are often at lower productivity levels. Additionaly, many of the higher productivity sectors in Ontario were dependent on exports, and exports were very hard hit by external shocks.

The situation was particularly acute in manufacturing, where 18 out of 20 sub-sectors ended up at a lower level than their previous peak, in some cases much lower. It is ironic that many analysts call for increased productivity as a way to increase Ontario's competitiveness. However, 
the causality tends to run the other way. It is the lack of competitiveness of some major facilities (due to an overvalued exchange rate) that previously had high productivity levels (as measured by GDP per hour worked) that caused them to be shut down, and reduced the average level of productivity in the economy.

If weak productivity growth is the result of weak exports growth, then there is nothing that the provincial government can do to remedy the situation. On the plus side, it is likely that the worst is behind us and there will be a gradual improvement in the coming years. Indeed, exports have bottomed out and have already turned up as a share of GDP. There is some hope for stronger growth in the United States in the coming years, boosting exports further. Yet, it is hard to predict what will happen to the Canadian dollar. While a high dollar will likely continue, the economy will gradually adjust to this reality, partly through downward adjustments to wage rates that can eventually (albeit slowly and painfully) restore competitiveness.

It is important to ensure that the current obstacles to exporting from Ontario are minimized, and if possible reversed. Hence, the Ontario government should continue to try to influence the federal government's position on the exchange rate and on international trade treaties. For example, it is possible that some tax levers could be used to provide greater benefits to exporting industries. ${ }^{20}$ Furthermore, it is likely that infrastructure and border issues have had a negative impact on Ontario's exports over the past several years. Some remedial action has been taken on that, but some aspects of it (such as the new bridge and road infrastructure at Windsor) will not be completed for many years.

Further research is needed to understand why Ontario's exports and manufacturing production suffered so much more than those of the ROC or the United States. The exchange rate and the heavy reliance on the auto sector is no doubt the largest part of the story, but without further analysis, we cannot be certain that it explains all of it. It is important to understand what might be different in terms of structure and the regulatory environment in Ontario as compared to the rest of North America that might have worsened Ontario's performance. Given the ongoing risks of adverse demand shocks, it is important to have a workforce that is as flexible as possible, to allow rapid movement out of declining sectors into growing ones. If it is found that Ontario has its own peculiar adverse institutional factors, it may be possible to fix those and achieve a more favourable outcome.

\section{References}

Baldwin, John and Beiling Yan (2010) "Export Market Dynamics and Plant-level Productivity: Impact of Tariff Reductions and Exchange Rate Cycles," Economic Analysis Research Paper Series, Statistics Canada.

Diewert, W. Erwin and Emily Yu (2012) "New Estimates of Real Income and Multifactor Productivity Growth for the Canadian Business Sector," International Productivity Monitor, No. 24, Fall, pp. 27-48.

Sharpe, Andrew and Eric Thomson (2010) "Insights into Canada's Abysmal Post-2000 Productivity Performance from Decompositions of Labour Productivity Growth by Industry and Province," International Productivity Monitor, No. 20, Fall, pp. 48-67.

Wooldridge, Jeffrey M. (2013) Introductory Econometrics: A Modern Approach, 5th ed. (Nashville: Southwestern).

20 The prevailing philosophy in taxation is a "level playing field" view that does not favour one sector over another. However, this approach is not supported by economic theory, which implies that lower tax rates should apply to sectors that face a higher price elasticity of demand. 